\title{
SPENT CARBIDE WASTE RETAINS TOXICITY LONG TERM AFTER DISPOSAL IN CAVES AND MINES
}

\author{
TOKSIČNOST KARBIDNIH ODPADKOV V JAMAH \\ IN RUDNIKIH
}

\author{
Andrew A. SEMIKOLENNYKH ${ }^{1 *}$, Anna A. RAHLEEVA ${ }^{1} \&$ Tatjana B. POPUTNIKOVA ${ }^{1}$
}

\begin{abstract}
UDC 546.261:551.435.84

Andrew A. Semikolennykh, Anna A. Rahleeva \& Tatjana B. Poputnikova: Spent carbide waste retains toxicity long term after disposal in caves and mines

We studied the environmental impact of wastes derived from calcium carbide, which is widely used for generating acetylene in industry and speleology. It was shown that spent carbide is toxic for biota and harmful to cave ecosystems and the surrounding environment. The toxic components of spent carbide waste were found to include calcium hydroxide, strontium and polycyclic aromatic hydrocarbons. The 50\% lethal doses (LD 50\%) of fresh spent carbide waste were calculated as $0.28-0.32 \mathrm{~g} / \mathrm{l}$ in biotests with daphnia, infusoria, and fishes. The toxicity of spent carbide declined only slowly over time, with toxicity still present in 13-year-old samples. Spent carbide should be disposed of with great care to ensure that it cannot be disseminated into natural water systems. Spent carbide deactivation could be provided within isolated bowls filled with water (micro sediment bowls) or within water-proof storage containers, and complete recycling could be achieved through the addition of deactivated waste to solid building materials. Keywords: carbide, cave, mine, waste, toxicity, impact.
\end{abstract}

Izvleček

UDK 546.261:551.435.84

Andrew A. Semikolennykh, Anna A. Rahleeva \& Tatjana B. Poputnikova: Toksičnost karbidnih odpadkov $v$ jamah in rudnikih

Proučevali smo okoljski vpliv odpadkov kalcijevega karbida, ki se uporablja v jamarstvu in industriji. Izkaže se, da so karbidni ostanki so toksični in škodljivi za jamsko okolje. Glavne toksične sestavine so calcijev hidroksid, stroncij in policiklični aromatski ogljikovodiki. 50\% smrtne doze (LD 50\%) izračunane iz biotestov na vodnih bolhah, infuzórijah in ribah so v območju 0.28-0.32 g/l. Toksičnost karbidnega apna s časom počasi upada, tudi 13 let stari vzorci so še vedno nevarni. Porabljen karbid ne sme priti v naravna vodna okolja. Pogosto ga odlagajo v betonske posode delno napolnjene $\mathrm{z}$ vodo (mikrosedimentne posode), še boljši način pa je odlaganje $\mathrm{v}$ popolno vodotesne hranilnike. Popolno reciklažo pa bi lahko dosegli z dodajanjem deaktiviranih ostankov $v$ gradbene materiale.

Ključne besede: karbid, jama, rudnik, toksičnost, vpliv na okolje.

\section{INTRODUCTION}

A number of karst caves and depleted mine sites contain waste previously disposed by tourist groups and speleological research expeditions. Disposed of by tourist equipment such as old ropes, fuel, and unused food are often accumulated in considerable amounts. Such wastes left behind by former and, occasionally, recent speleological expeditions can present a serious negative anthropogenic impact on the subterranean ecosystems, new cave visitors, and a whole local population due to the risk of ground water pollution often affecting the regional drinking water supply. In this article we present the results of our research into the negative effects of spent calcium carbide as a hazardous waste.

\footnotetext{
${ }^{1}$ Soil Science Faculty, Moscow State University, Russia, e-mail: aasemik@list.ru

Received/Prejeto: 13.9.2010
} 
Calcium carbide is widely used in industrial acetylene production for welding tools and in chemical synthesis. It is also used in caving to fuel acetylene lamps. Spent carbide is usually left by some cavers anywhere in caves where the recharging of gas-generators takes place, and over many years this can result in substantial accumulations of such wastes (carbide dumps). The problem of carbide disposal has a long history. By the present time the use of carbide lamps is highly restricted in some countries (Australia, USA, New Zealand, etc.). However, such lamps are still used in many other countries, and large carbide dumps are present in many caves.

Pure calcium carbide (synonyms: acetylenogen, calcium acetylide, and calcium dicarbide) $-\mathrm{CaC}_{2}-$ is a white crystalline substance. The modern industrial synthesis of $\mathrm{CaC}_{2}$ involves high-temperature combustion of a mixture of calcium oxide and coke (A dictionary... 2004).

$$
\mathrm{CaO}+3 \mathrm{C} \rightarrow \mathrm{CaC}_{2}+\mathrm{CO}
$$

Industrial calcium carbide is usually produced from impure raw materials (ignited crystalline limestone, ash-rich coke, coal, etc.). A technique for solid organic wastes utilization by reaction with calcium oxide has also been developed. Such technological processes result in the production of dark-grey carbide colored by coallike substances. Impurities present in carbide can also include calcium phosphide and sulphide, which account for the unpleasant smell of carbide and the acetylene produced.

The reaction of calcium carbide with water creates acetylene:

$$
\mathrm{CaC}_{2}+2 \mathrm{H}_{2} \mathrm{O} \rightarrow \mathrm{C}_{2} \mathrm{H}_{2}+\mathrm{Ca}(\mathrm{OH})_{2}
$$

For many years cavers believed that the use of calcium carbide was harmless for human health and the environment. That commonly-held view was substantiated by the fact that the waste's main chemical compound is calcium hydroxide $-\mathrm{Ca}(\mathrm{OH})_{2}$, which reacts over time with atmospheric carbon dioxide to form non-toxic calcium carbonate.

The first experiments to investigate spent carbide toxicity for microorganisms were conducted by Agagab- yan (1955). An aquatic solution of the waste at $0.5 \%$ concentration (waste:water $=1: 200$ ) caused bacterial cell death within 10 minutes. It was also shown that grampositive bacteria tend to be more resistant to spent carbide than gram-negative bacteria.

The key research into the toxic effects of spent calcium carbide on Ptomaphagus hirtus cave beetles was conducted by Peck (1969). Here, the toxic effect of carbide on beetle eggs was shown to result in the death of all hatched larvae. At the same time, the control population developed normally.

A comprehensive analysis of the spent carbide toxicity was carried out by Lavoie (1980) who conducted a series of in situ and in vitro experiments. It was shown that calcium carbide waste causes the death of most microorganisms within 10 minutes, even if applied at concentrations as low as $0.1 \%$ (waste:water $=1: 1000$ ). However, the number of microorganisms found under the waste in the cave floor was comparable with that occurring in the non-waste control area. This phenomenon was interpreted by Lavoie to be a result of the neutralization of spent carbide toxicity upon contact and reaction with atmospheric carbon dioxide. The main cause of such toxicity was a high pH (about 11.2) of the waste. The experiments on neutralizing the waste demonstrated that its $\mathrm{pH}$ reduced from 11.2 to 6.3 within 25 days in a natural cave environment and within 10 days under forced additional aeration. The replicated experiment with the carbide waste neutralized to $\mathrm{pH} 6.3 \mathrm{dem}$ onstrated an absence of toxic effects to E. coli within a period of 60 minutes. The general conclusion by Lavoie was that the waste is highly toxic, but loses its toxicity within a short period of time, and that the toxic effect is manifested only within small areas of a cave.

The aims of our study were to investigate the negative impact of calcium carbide waste by analyzing the following key points:

- chemical composition of different treatments of technical carbide;

- transformation of the waste in time under cave conditions and upon treatment with water;

- toxic effects of the waste on different organisms;

- possible path-ways of ecologically safe waste utilization.

\section{STUDY SAMPLES}

Two series of samples were used in our experiments to identify the degree of toxicity and spatial migration of the toxic substances present within spent carbide. Sampling procedures included collection of $100 \mathrm{~g}$ samples of mate- 
rial in plastic bags. Samples were stored until processing in a refrigerator at $+4^{\circ} \mathrm{C}$ in closed bags.

Series I. Sample freshly prepared in laboratory and exposed in a mine for a month.

Fresh waste of calcium carbide (sample 1a) was prepared for our experiment by reaction of calcium carbide with water inside a gas generator cylinder designed to produce acetylene for illumination. The fresh waste appeared as a moist powder (water content was 25\% by mass), weakly aggregated (crumbly), light grey with occasional small dark and white mottles, with an acrid odor.

The experiment using the above sample was set up in the Nikitskaya Mine, south-west of Moscow, Russia (abandoned underground limestone mine, also known as Nikitskaya Quarry). A level patch of a clay ground was used as a treatment plot. After taking a clay sample for microbiological analysis, a $100 \mathrm{~g}$ of the fresh waste (sample 1a) was distributed within a $10 \times 10 \mathrm{~cm}$ area at the surface of the treatment plot. After one month, the $0-1 \mathrm{~cm}$ layer of ground just below the waste deposit was sampled for microbiological analysis; a control sample was taken from random points more than $1 \mathrm{~m}$ away from the waste deposit. A sample of the remaining waste (sample 1b) was also collected for determination of its chemical composition and toxic properties after the exposure. A portion of sample $1 \mathrm{~b}$ was pre-treated with water (see methods section), and then the solid residue (sample 1c) was analyzed for its chemical composition and toxicity.
Series II: Samples of wastes exposed for different time periods in caves and quarries.

The sampling strategy was aimed at collecting spent carbide samples that were exposed under the cave environment for different time periods. The samples were taken from waste piles left by cavers in separate underground locations at specified times (information from personal communications). It should be mentioned that, inevitably, such samples originated from different calcium carbide manufacturers.

Sample 2 - from the aforementioned Nikitskaya Mine (Moscow area, Russia), the 'Amphitheatre' Cavern, $150 \mathrm{~m}$ from the entrance; exposed for a period of 1-2 years.

Sample 3 - from the Nikitskaya Mine, a tunnel about $300 \mathrm{~m}$ from the entrance; exposed for a period of 3-4 years.

Sample 4 - from Snezhnaya, the Snow Cave (Bzybskiy Ridge, Abkhazia), near the Gremyachiy (Roaring) Cavern; exposed for a period of 2 weeks.

Sample $5 a$ - from the Barenschacht Cave (Switzerland), a semi-siphon area, the depth of $550 \mathrm{~m}$; exposed for a period of 13 years.

Sample $5 b$ - water-treated portion of unground $5 \mathrm{a}$ sample.

Sample $5 c$ - water-treated portion of the 5 a sample ground using a porcelain mortar and pestle.

The certified chemically pure fresh calcium hydroxide $\left(\mathrm{Ca}(\mathrm{OH})_{2}\right)$ was used as a $\mathrm{pH}$ control sample.

\section{MATERIALS AND METHODS}

Bulk chemical composition of solid wastes was determined by the energy-dispersive $\mathrm{x}$-ray fluorescence method (Fitton 1997). The instrument "TEFA" produced by OPTEK Ink. was used.

Determination of organic and carbonate carbon was done by the method of dry combustion in oxygen flow at $1,000^{\circ} \mathrm{C}$ (Nelson \& Sommers 1996) followed by measuring the emitted carbon dioxide by coulometric titration using an automatic analyzer AN-7529 with combusting device US-7077 (produced by PO "Izmeritel", Gomel, Belorussia). Samples for organic carbon determination were pre-treated with hydrochloric acid. Untreated samples were used for determining the total carbon. The carbonate (inorganic) carbon was calculated as the difference between the total and organic carbon.
Polyaromatic compounds were analyzed using the high performance liquid chromatography method and methylated spirit extraction. Polyaromatic compounds were divided in the C18 type column with liquid phase "acetonitrile/water" and measured by a "Stayer" chromatograph with ultraviolet detector.

The water-treated samples and water extractions were obtained by mixing the waste with DDI water at the solid-to-liquid ratio of 1:10 and subjecting to four hours rotation at 240 turns per minute.

Biotesting was carried out on three different organisms: infusoria, daphnia, and fishes. The cultures of organisms were supported in the "LETAP" collection of the Laboratory of Ecotoxicology (Soil Science Faculty, Moscow State University). 
Biotesting on infusoria (Paramecium caudatum) Ehrenberg for toxicity determination was performed in a micro-aquarium with individual compartments. Ten to twelve individual cells were placed in each compartment using a capillary pipette. Then $0.6 \mathrm{ml}$ of pure drinking water was added to control compartments, and $0.6 \mathrm{ml}$ of test extractions was added to test compartments. All tests were done with five replications, i.e., each test solution was dropped into five compartments containing in total at least 50 infusorians. The exact number of individuals in each compartment was counted under a microscope. Once the start time of biotesting had been recorded, the micro-aquarium with the filled compartments was placed for 24 hours into an incubator set at $22-24^{\circ} \mathrm{C}$. In acute toxicity tests and their diluted versions we identified the mean lethal concentration of pollutant, i.e., the dose which would be fatal to $50 \%$ of the test-objects over a 24-hour exposure.

Biotesting on Daphnia magna Straus was carried out in three-replications using one-day-old daphnia. Glass cylinders were filled with $100 \mathrm{ml}$ of either test extraction or control solution, and then 10 daphnia individuals were placed into each glass cylinder. After 96-hours of exposure the numbers of surviving crustaceans were recorded.

Biotesting on fish (Danio rerio Hamilton-Buchanan) was conducted. Two-week old fish were placed in tanks at a density of one individual per one liter of pure drinking water (control) or the same volume of test solution at the temperature of $23^{\circ} \mathrm{C}$, aerated using an air-pump for two hours daily. The experiment was done with five replications. The mortality of fish over a period of 96 hours indicated the degree of toxicity. The fish were not fed during the experiment.
The LD50 values were determined using a Probitanalysis (type of regression analysis). A Probit (probability unit) is a probability value corresponding to the percentage of response. The statistical significance of each experimental value depends on its deviation from standard toxic doses. Regression lines in the 'LgD-Probit' coordinates allow for a graphical determination of LD values (Finney 1971).

Seed germination tests were conducted using the seed of oats (Avena sativa) 100-ml pots, factory-produced seedling compost (with $\mathrm{pH}$ of 5.5-6.0 and nutrient concentrations as follows: $\mathrm{N}-150-250 \mathrm{mg} / \mathrm{l}, \mathrm{P}_{2} \mathrm{O}_{5}$ - 120-150 mg/l and $\mathrm{K}_{2} \mathrm{O}-150-300 \mathrm{mg} / \mathrm{l}$ ) and spent calcium carbide. The four experimental treatments, each replicated twice, had different volume proportions of the waste mixed with the compost: 1) 100\% compost (control treatment); 2) $90 \%$ of compost and $10 \%$ of waste, 3 ) $75 \%$ of compost and $25 \%$ of waste and 4) $50 \%$ of compost and $50 \%$ waste (by volume). Ten oat seeds were planted at a depth of 3-5 $\mathrm{mm}$ in each pot, watered to reach the soil moisture of $60 \%$ and incubated at $23^{\circ} \mathrm{C}$. The seed germination time and seedling number and height were recorded on the $3^{\text {rd }}, 7^{\text {th }}$ and $11^{\text {th }}$ day of experiment.

Microbiological analyses of the samples of cave floor soil involved the preparation of soil suspensions at different degrees of dilution (different soil-to-water ratios) that were inoculated on nutrient agar (hydrolyzed power of fish meat $-24 \mathrm{~g} / \mathrm{l}, \mathrm{NaCl}-4 \mathrm{~g} / \mathrm{l}$, agar - $12 \mathrm{~g} / \mathrm{l} ; \mathrm{pH}-7.3$; produced by State Research Center for Applied Microbiology \& Biotechnology (Obolensk, Russia) and incubated at $27^{\circ} \mathrm{C}$ for five days. Then the number of colony forming units (CFU) was counted in tree replications and the average number was calculated.

\section{RESULTS AND DISCUSSION}

The data on the bulk chemical composition of calcium carbide waste samples are presented in Tab. 1. The waste samples were composed mainly of calcium and, to a lesser extent, magnesium compounds (probably hydroxides) that made up about $90 \%$ of the sample mass. The content of stable mineral impurities from silica, aluminum, and iron was about $5-7 \%$. The concentrations of heavy metals were generally insignificant. However, the concentrations of sulfur and strontium were high. We can suggest that some part of strontium is bound with sulfur in a stable form. The variation in strontium concentrations is probably associated with the samples origin from different calcium carbide manufacturers.
The bulk chemical composition of water-treated samples 1c (fresh waste exposed for 1 month), $5 \mathrm{~b}$ (unground 13-year-old waste) and 5c (grounded 13-year-old waste) was characterized by slightly lower concentrations of potassium and strontium and slightly higher concentrations of aluminum, silica and magnesium. Generally, the assemblage of chemical elements did not change upon contact with water.

The data on the organic and carbonate carbon distribution in the samples are presented in Tab. 2. The organic carbon content in most samples was about up to $2 \%$, except for the old waste sample $5 \mathrm{a}$ that contained $3.55 \%$ of organic carbon. The reaction of organic carbon 
Tab. 1: The bulk chemical composition (macro elements are converted to oxides) of spent carbide samples.

\begin{tabular}{|c|c|c|c|c|c|c|c|c|c|c|c|c|c|c|c|c|c|c|c|c|c|c|}
\hline$\frac{\tilde{a}}{\frac{a}{\xi}}$ & 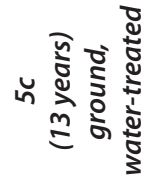 & \begin{tabular}{l} 
Ln \\
\multirow{\infty}{\infty}{} \\
0 \\
0
\end{tabular} & $\stackrel{m}{0}$ & $\begin{array}{l}\overline{8} \\
\dot{0} \\
\mathrm{~V}\end{array}$ & $\frac{\overline{0}}{0}$ & бо & $\frac{\tilde{m}}{\dot{0}}$ & $\frac{\stackrel{n}{m}}{\stackrel{m}{\sim}}$ & $\begin{array}{l}\stackrel{0}{0} \\
\text { ó }\end{array}$ & $\begin{array}{l}0 \\
\infty \\
\circ \\
0\end{array}$ & $\begin{array}{l}\bar{\delta} \\
\dot{0} \\
\mathrm{v}\end{array}$ & $\begin{array}{l}\text { ¿ } \\
\text { ठ }\end{array}$ & $\begin{array}{l}\stackrel{\infty}{\uparrow} \\
\stackrel{+}{0} \\
0\end{array}$ & $\bar{v}$ & $\bar{v}$ & $\stackrel{\bullet}{\sim}$ & $\bar{v}$ & $\bar{v}$ & $\bar{v}$ & $\frac{a}{\sim}$ & 0 & શે \\
\hline 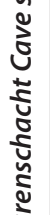 & 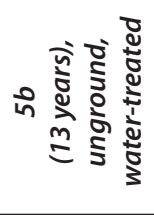 & 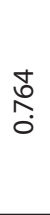 & 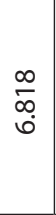 & $\begin{array}{l}\bar{\delta} \\
\text { ○े } \\
\text { V }\end{array}$ & $\begin{array}{l}\text { ñ } \\
\text { ஸุ } \\
0\end{array}$ & $\frac{8}{\circ}$ & $\frac{\infty}{\stackrel{\infty}{\sigma}}$ & \begin{tabular}{l}
$\hat{N}$ \\
$\stackrel{\infty}{\sim}$ \\
\multirow{\gamma}{*}{}
\end{tabular} & $\begin{array}{l}\text { ô } \\
\text { กุ? } \\
0\end{array}$ & $\frac{\stackrel{\circ}{ }}{0}$ & $\begin{array}{l}\bar{\delta} \\
\dot{0} \\
\mathrm{v}\end{array}$ & $\begin{array}{l}\circ \\
\circ \\
\circ\end{array}$ & $\begin{array}{l}\hat{n} \\
0 \\
0 \\
0\end{array}$ & $\bar{v}$ & $\bar{v}$ & $\stackrel{m}{r}$ & $\bar{v}$ & $\bar{v}$ & $\bar{v}$ & $\stackrel{\stackrel{N}{N}}{ }$ & $\stackrel{ \pm}{\leftarrow}$ & $\bar{\sigma}$ \\
\hline$\infty$ & ผ゚ & $\begin{array}{l}\infty \\
0 \\
\text { ஸी? } \\
0\end{array}$ & $\begin{array}{l}\text { nू } \\
\text { ஸ̃ }\end{array}$ & $\begin{array}{l}\bar{\delta} \\
\dot{0} \\
\mathrm{v}\end{array}$ & 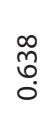 & $\frac{\check{O}}{\circ}$ & ָ̃ & $\begin{array}{l}\stackrel{n}{\stackrel{n}{n}} \\
\stackrel{f}{f}\end{array}$ & $\frac{0}{\dot{t}}$ & oి & চ & $\begin{array}{l}\bar{\delta} \\
\dot{0} \\
\mathrm{v}\end{array}$ & $\underset{0}{\stackrel{1}{f}}$ & $\bar{v}$ & $\mp$ & $\mp$ & 0 & $\bar{v}$ & $\bar{v}$ & $\stackrel{\mathbb{N}}{\sim}$ & 으 & $\stackrel{\mathcal{F}}{\mathcal{F}}$ \\
\hline 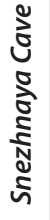 & 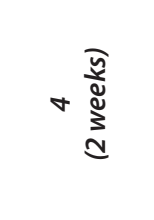 & $\stackrel{\hat{n}}{\hat{0}}$ & $\underset{\text { N̦ }}{\stackrel{N}{N}}$ & $\begin{array}{l}\overline{8} \\
\text { ○े }\end{array}$ & 竎 & $\begin{array}{l}\stackrel{0}{0} \\
\text { Oे }\end{array}$ & $\begin{array}{l}\bar{\delta} \\
\dot{0} \\
\mathrm{v}\end{array}$ & 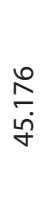 & $\begin{array}{l}\stackrel{0}{m} \\
\text { ర్} \\
0\end{array}$ & $\frac{\hat{N}}{\circ}$ & $\begin{array}{l}\bar{\delta} \\
\dot{0} \\
\mathrm{v}\end{array}$ & $\begin{array}{l}\overline{8} \\
\text { ○े } \\
\mathrm{V}\end{array}$ & กֶ̂ & $\bar{v}$ & 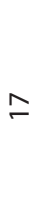 & $\mp$ & in & $\bar{v}$ & $\bar{v}$ & กิ & & 우 \\
\hline \multirow{5}{*}{ 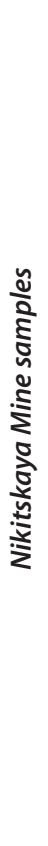 } & 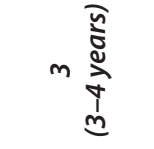 & 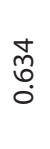 & $\begin{array}{l}\text { స్ } \\
\text { ก่ }\end{array}$ & $\begin{array}{l}\overline{8} \\
\dot{0} \\
\mathrm{v}\end{array}$ & $\underset{N}{ָ}$ & $\begin{array}{l}\text { 융 } \\
\text { 웅 }\end{array}$ & $\begin{array}{l}\infty \\
\stackrel{\infty}{\circ} \\
\end{array}$ & $\begin{array}{l}\text { ํㅜㅁ } \\
\text { in } \\
\text { ñ }\end{array}$ & $\frac{0}{\frac{0}{0}}$ & ธิ & $\begin{array}{l}\bar{\delta} \\
\dot{0} \\
\mathrm{v}\end{array}$ & $\begin{array}{l}\text { ᄋे } \\
\text { ठ }\end{array}$ & 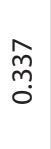 & $\bar{v}$ & $\bar{v}$ & $\bar{v}$ & $\bar{v}$ & $\bar{v}$ & $\bar{v}$ & $\stackrel{\circ}{\stackrel{ }{N}}$ & 으 & ষ \\
\hline & 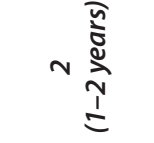 & $\begin{array}{l}\text { กี } \\
\text { กิ }\end{array}$ & $\begin{array}{l}\varnothing \\
\varnothing \\
0\end{array}$ & $\begin{array}{l}\overline{8} \\
\stackrel{0}{ }\end{array}$ & $\begin{array}{l}\text { 노 } \\
\text { ర్ } \\
0\end{array}$ & 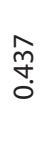 & $\begin{array}{l}\text { ț } \\
\text { : }\end{array}$ & $\begin{array}{l}\text { જे } \\
\text { ஸें }\end{array}$ & \begin{tabular}{l}
$\circ$ \\
\hdashline \\
0
\end{tabular} & $\frac{m}{\frac{m}{0}}$ & $\overbrace{0}^{m}$ & $\begin{array}{l}\circ \\
\text { 움 }\end{array}$ & $\frac{n}{n}$ & $\bar{v}$ & $\bar{v}$ & $\bar{\sim}$ & 0 & $\bar{v}$ & $\bar{v}$ & $\begin{array}{l}\stackrel{L}{\infty} \\
\stackrel{\mathcal{D}}{N}\end{array}$ & $\wedge$ & กี \\
\hline & 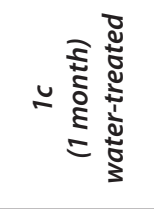 & ồ & $\begin{array}{l}\text { 守 } \\
\text { ホ. }\end{array}$ & $\begin{array}{l}\overline{8} \\
\dot{\circ} \\
\dot{v}\end{array}$ & $\frac{m}{\infty}$ & 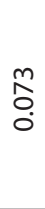 & $\frac{8}{\circ}$ & 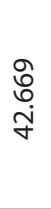 & $\begin{array}{l}\text { ñ } \\
\text { గొ } \\
0\end{array}$ & 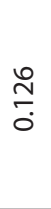 & চ̊ & 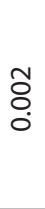 & $\begin{array}{l}\frac{n}{n} \\
\text { ñ } \\
0\end{array}$ & $\bar{v}$ & $\stackrel{\sim}{ }$ & $\stackrel{\Perp n}{\sim}$ & $\bar{v}$ & $\bar{v}$ & $\bar{v}$ & f & $a$ & 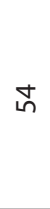 \\
\hline & 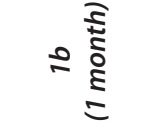 & $\begin{array}{l}\text { \&े } \\
\text { مे }\end{array}$ & 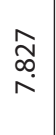 & $\begin{array}{l}\overline{8} \\
\dot{0} \\
\mathrm{~V}\end{array}$ & $\begin{array}{l}\stackrel{n}{\infty} \\
\stackrel{\infty}{N} \\
0\end{array}$ & $\begin{array}{l}\infty \\
\stackrel{\infty}{\circ} \\
0\end{array}$ & 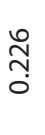 & $\begin{array}{l}\stackrel{N}{~} \\
\stackrel{+}{\forall}\end{array}$ & $\begin{array}{l}\hat{\infty} \\
\text { ก̂? } \\
0\end{array}$ & $\frac{8}{\circ}$ & চ & ํ. & $\begin{array}{c}\bar{\infty} \\
m \\
0\end{array}$ & $\bar{v}$ & $\bar{v}$ & 은 & $a$ & 0 & $\bar{v}$ & $\underset{f}{\stackrel{丶}{*}}$ & $=$ & ๑ \\
\hline & 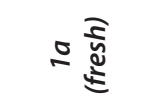 & 年 & $\begin{array}{l}\text { Na } \\
\infty \\
\text { เnं }\end{array}$ & $\begin{array}{l}\bar{\delta} \\
\dot{0} \\
\mathrm{v}\end{array}$ & ஸે & $\begin{array}{l}\bar{\delta} \\
\dot{0} \\
\mathrm{v}\end{array}$ & $\frac{\underset{1}{0}}{0}$ & 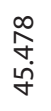 & $\stackrel{\bar{\infty}}{\stackrel{\sim}{\longrightarrow}}$ & $\begin{array}{l}\infty \\
\circ \\
0 \\
0\end{array}$ & 今̊ & $\begin{array}{l}m \\
\text { O̊ } \\
0\end{array}$ & 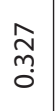 & $\stackrel{\llcorner}{\sim}$ & in & $\infty$ & $\bar{v}$ & $\bar{v}$ & $\nabla$ & 윰 & $a$ & 0 \\
\hline & 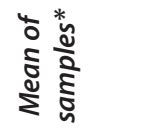 & 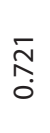 & Ё & 0 & $\underset{\stackrel{\overbrace{}}{+}}{\circ}$ & $\frac{\mathfrak{n}}{\stackrel{0}{0}}$ & $\frac{\hat{\infty}}{\sigma}$ & 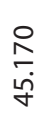 & $\begin{array}{l}\overline{0} \\
\text { ᄂñ }\end{array}$ & $\frac{8}{\circ}$ & $\begin{array}{l}\text { ণ } \\
\text { О } \\
0\end{array}$ & $\begin{array}{l}m \\
\circ \\
\circ\end{array}$ & 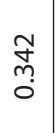 & $a$ & $\begin{array}{l}\mathscr{0} \\
\dot{0}\end{array}$ & ָָ & $\stackrel{\forall}{\dot{m}}$ & 0 & $\stackrel{\infty}{0}$ & $\begin{array}{l}\stackrel{N}{n} \\
\stackrel{n}{n}\end{array}$ & $\stackrel{N}{N}$ & $\begin{array}{l}\infty \\
\stackrel{\infty}{m}\end{array}$ \\
\hline & 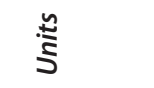 & do & $\partial^{\circ}$ & ১0 & $\partial^{\circ}$ & ১0 & ○ & ¿0 & $\partial^{\circ}$ & $\delta^{\circ}$ & ১0 & ১0 & ○ & す) & 일 & के & すे & $\begin{array}{l}\text { ळे } \\
\text { 2 }\end{array}$ & 일 & के & 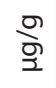 & $\frac{\text { o }}{2}$ \\
\hline & 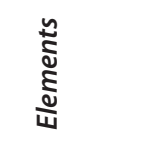 & $\frac{O_{N}^{m}}{\mathbb{L}}$ & $i^{N}$ & $O_{Q^{n}}^{n}$ & $O^{m}$ & $\bar{v}$ & $\begin{array}{l}\text { ON } \\
\Upsilon^{\prime}\end{array}$ & ○ & $\stackrel{\circ}{\text { Ŏ }}$ & $\stackrel{0}{ }^{N}$ & $\begin{array}{l}\mathcal{O}^{m} \\
\end{array}$ & $\begin{array}{l}\stackrel{O}{c} \\
\sum\end{array}$ & $\begin{array}{l}\stackrel{\sim}{\sim}^{m} \\
\underset{\sim}{m}\end{array}$ & $\bar{z}$ & $\bar{U}$ & $\tilde{N}$ & $\ddot{z}$ & $\bar{\oplus}$ & $\frac{0}{\alpha}$ & $\grave{n}$ & $>$ & $\bar{N}$ \\
\hline
\end{tabular}


Tab. 2: The total, inorganic and organic carbon content (\%) in the spent carbide samples, sorted by duration of exposure in the caves.

\begin{tabular}{l|l|l|c|c|c}
\hline \multicolumn{2}{c|}{ Samples } & \multicolumn{3}{c}{ Carbon content, $\%$} \\
\hline No. & Location & Age & Total & Carbonate & Organic \\
\hline $1 \mathrm{a}$ & Prepared in laboratory & fresh & 1.55 & 0 & 1.55 \\
\hline 4 & Snezhnaya Cave & 2 weeks & 1.76 & 0.41 & 1.35 \\
\hline $1 \mathrm{~b}$ & Nikitskaya Qaurry & 1 month & 3.26 & 1.08 & 1.68 \\
\hline $1 \mathrm{c}$ & Nikitskaya Mine & 1 month & 4.89 & 3.31 & 1.58 \\
\hline 3 & Nikitskaya Mine & $3-4$ years & 6.21 & 4.31 & 1.9 \\
\hline $5 \mathrm{a}$ & Barenschacht Cave & 13 years & 9.96 & 6.41 & 3.55 \\
\hline $5 \mathrm{~b}$ & Barenschacht Cave & 13 years & 8.34 & 6.51 & 1.83 \\
\hline $5 \mathrm{c}$ & Barenschacht Cave & 13 years & 9.38 & 9.25 & 0.13 \\
\hline
\end{tabular}

Tab. 3: The organic matter compounds within the fresh spent carbide sample (1a).

\begin{tabular}{l|c}
\hline Compounds & Content, $\mathbf{m g} / \mathbf{k g}$ \\
\hline Phenols (total) & 22.80 \\
\hline Cresols (total) & 11.00 \\
\hline Benzol & 0.54 \\
\hline Toluol & 2.06 \\
\hline Ethers of carbonic acids & 9.50 \\
\hline Polyaromatic compounds (total), including: & 11.48 \\
\hline Fluorene & 10.40 \\
\hline Anthracene & 0.17 \\
\hline Pyrene & 0.30 \\
\hline Benzo[a]pyrene & 1.05 \\
\hline Other polyaromatic compounds & 0.56 \\
\hline
\end{tabular}

to water treatment was not fully understood. We expected the organic carbon to be represented by coal particles, and therefore, that the amount of the organic matter should not change upon treatment in water. Indeed, such changes were insignificant in the water-treated sample of relatively fresh waste (1c). However, in old waste samples (5b \& 5c) a significant part of organic carbon was lost after water treatment.

The fresh waste (sample 1a) did not contain carbonates. The process of carbonization of calcium hydroxide begins somewhat later and develops slowly. After one month's exposure in a cave environment the content of carbonate carbon reached $1.08 \%$ (sample $1 \mathrm{~b}$ ). The waste

Tab. 4: The mortality (\%) of daphnia (Daphnia magna), infusoria (Paramecium caudatum), and fishes (Danio rerio) in biotesting of spent carbide toxicity. Simple averages of the five replicates.

\begin{tabular}{|c|c|c|c|c|c|}
\hline \multirow[b]{2}{*}{ Waste: water ratio } & \multicolumn{3}{|c|}{ Nikitskaya Mine } & \multirow{2}{*}{$\begin{array}{c}\text { Barenschacht Cave, } \\
\text { sample 5a } \\
\text { (13 лет) }\end{array}$} & \multirow{2}{*}{$\begin{array}{c}\text { Pure fresh } \\
\mathrm{Ca}(\mathrm{OH})_{2}\end{array}$} \\
\hline & $\begin{array}{c}\text { sample 1a } \\
\text { (fresh) }\end{array}$ & $\begin{array}{l}\text { sample } 1 b \\
\text { (1 month) }\end{array}$ & $\begin{array}{c}\text { sample } 3 \\
\text { (3-4 years) }\end{array}$ & & \\
\hline \multicolumn{6}{|l|}{$\mathrm{pH}$} \\
\hline $1: 10$ & 12.5 & 12.8 & 10.5 & 12.4 & 12.8 \\
\hline $1: 100$ & 9.6 & 11.6 & 8.8 & 11.3 & 11.3 \\
\hline $1: 1000$ & 8.7 & 7.4 & 6.8 & 7.1 & 8.1 \\
\hline \multicolumn{6}{|c|}{ Biotesting on Daphnia magna } \\
\hline water (control) & 0 & 0 & 0 & 0 & 0 \\
\hline $1: 10$ & 100 & 100 & 100 & 100 & 100 \\
\hline $1: 100$ & 70 & 83 & 54 & 55 & 0 \\
\hline $1: 1000$ & 40 & 10.3 & 0 & 41.4 & 0 \\
\hline $1: 10000$ & 0 & 0 & 0 & 0 & 0 \\
\hline \multicolumn{6}{|c|}{ Biotesting on Paramecium caudatum } \\
\hline water (control) & 0 & 0 & 0 & 0 & 0 \\
\hline $1: 10$ & 100 & 100 & 100 & 100 & 100 \\
\hline 1:100 & 70 & 98 & 51 & 78 & 30 \\
\hline 1:1000 & 40 & 0 & 0 & 32 & 12 \\
\hline $1: 10000$ & 0 & 0 & 0 & 0 & 0 \\
\hline \multicolumn{6}{|c|}{ Biotesting on Danio rerio } \\
\hline water (control) & 0 & \multicolumn{4}{|c|}{ ND } \\
\hline $1: 10$ & 100 & \multicolumn{4}{|c|}{ ND } \\
\hline $1: 100$ & 100 & \multicolumn{4}{|c|}{ ND } \\
\hline $1: 1000$ & 0 & \multicolumn{4}{|c|}{ ND } \\
\hline $1: 10000$ & 0 & \multicolumn{4}{|c|}{ ND } \\
\hline
\end{tabular}

${ }^{\star} \mathrm{ND}$ - not determined 
Tab. 5: The 50\% lethal dose (LD 50\%, gram waste per a liter) of spent carbide in biotests with daphnia (Daphnia magna), infusoria (Paramecium caudatum), and fishes (Danio rerio).

\begin{tabular}{|c|c|c|c|c|c|}
\hline \multirow[b]{2}{*}{ Waste: water ratio } & \multicolumn{3}{|c|}{ Nikitskaya Mine } & \multirow{2}{*}{$\begin{array}{c}\text { Barenschacht Cave, } \\
\text { sample } 5 a \\
\text { (13 years) }\end{array}$} & \multirow{2}{*}{$\begin{array}{c}\text { Pure fresh } \\
\mathrm{Ca}(\mathrm{OH})_{2}\end{array}$} \\
\hline & $\begin{array}{c}\text { sample 1a } \\
\text { (fresh) }\end{array}$ & $\begin{array}{l}\text { sample } 1 b \\
\text { (1 month) }\end{array}$ & $\begin{array}{c}\text { sample } 3 \\
\text { (3-4 years) }\end{array}$ & & \\
\hline \multicolumn{6}{|c|}{ Biotesting on Daphnia magna } \\
\hline LD 50\% & 0,28 & 0,35 & 0,69 & 0,33 & 2,15 \\
\hline \multicolumn{6}{|c|}{ Biotesting on Paramecium caudatum } \\
\hline LD 50\% & 0,28 & 0,35 & 0,71 & 0,28 & 0,62 \\
\hline \multicolumn{6}{|c|}{ Biotesting on Danio rerio } \\
\hline LD 50\% & 0,32 & \multicolumn{4}{|c|}{ ND } \\
\hline
\end{tabular}

${ }^{\star} \mathrm{ND}$ - not determined

Tab. 6: The decline of oat seedling development (as \% reduction of control parameters) as a result of spent carbide addition to compost. Simple averages of the two replicates.

\begin{tabular}{l|l|c|c|c|c}
\hline \multirow{2}{*}{$\begin{array}{l}\text { Percentage of } \\
\text { waste in compost }\end{array}$} & $\begin{array}{l}\text { Seedling growth } \\
\text { parameters }\end{array}$ & $\begin{array}{c}\text { Nikitskaya Mine } \\
\text { sample 1a } \\
\text { (fresh) }\end{array}$ & $\begin{array}{c}\text { sample 1b } \\
\text { (1 month) }\end{array}$ & $\begin{array}{c}\text { sample 1c } \\
\text { (1 month) } \\
\text { water-treated }\end{array}$ & $\begin{array}{c}\text { Barenschacht Cave, } \\
\text { sample 5a } \\
\text { (13 years) }\end{array}$ \\
\hline \multirow{2}{*}{\begin{tabular}{l} 
(control) \\
\multirow{2}{*}{$10 \%$}
\end{tabular}} & Sprouts height & 0 & 0 & 0 & 0 \\
\cline { 2 - 6 } & Sprouts number & 0 & 0 & 0 & 0 \\
\hline \multirow{2}{*}{$25 \%$} & Sprouts height & 40 & 10 & 0 & 30 \\
\cline { 2 - 6 } & Sprouts number & 45 & 10 & 0 & 70 \\
\hline \multirow{2}{*}{$50 \%$} & Sprouts height & 85 & 40 & 10 & 70 \\
\cline { 2 - 6 } & Sprouts number & 90 & 50 & 25 & 100 \\
\hline
\end{tabular}

Tab. 7: Results of the micro-biological analysis of mine floor soil samples.

\begin{tabular}{l|l|c|c|c}
\hline \multirow{2}{*}{$\begin{array}{l}\text { Samples from Nikitskaya } \\
\text { Mine }\end{array}$} & \multirow{2}{*}{ Age } & \multicolumn{3}{|c}{ Number of colony-forming units per 1 $\mathrm{g}$ of dry soil } \\
\cline { 3 - 5 } & & before waste disposal & under waste pile & $1 \mathrm{~m}$ away from waste pile \\
\hline Sample 1b & 1 month & $1.3 \times 10^{5}$ & $0.4 \times 10^{3}$ & $1.0 \times 10^{5}$ \\
\hline Sample 2 & $1-2$ years & ND & $1.2 \times 10^{5}$ & $1.6 \times 10^{5}$ \\
\hline Sample 3 & 3-4 years & ND & $1.0 \times 10^{5}$ & $1.4 \times 10^{4}$ \\
\hline
\end{tabular}

${ }^{\star} \mathrm{ND}$ - not determined

exposed for 3-4 years (sample 3) contained more than $4 \%$ of carbonate carbon, and the 13-year-old waste samples (5a, 5b \& 5c) contained about $6.5 \%$ of carbonate carbon. The rate of carbonization increases upon waste contact with water as was seen in samples $1 c, 5 b$ and especially $5 c$, because the latter was ground prior to mixing with water.

Data on the organic matter compounds from the fresh spent carbide sample (1a) are presented in Tab. 3. The measurements of $\mathrm{pH}$ in water (Tab. 4) showed that the spent carbide samples were strongly alkaline, which is hazardous for the environment. The $\mathrm{pH}$ of most samples was above 12 (except for sample 3 with $\mathrm{pH}$ of 10.5). This can be explained by the waste composition which is mostly slaked lime $\left(\mathrm{Ca}(\mathrm{OH})_{2}\right)$ having a $\mathrm{pH}$ of 12.8 in pure form.

The research by Lavoie (1980) revealed that a few weeks was enough for natural neutralization of $\mathrm{pH}$, if the waste remained in water solution. However, our research on air-exposed waste has shown that such waste does not change into calcium carbonate for at least a decade, and even over 13 years the $\mathrm{pH}$ of such waste still remains strongly alkaline. Only dilution at a waste-to-water ratio of 1:1000 causes a decrease in $\mathrm{pH}$ sufficient for it to be harmless for the environment (Tab. 4).

The results of biotesting of spent carbide samples for toxicity are also presented in Tab. 4 . Waste concentration causing death of more than $50 \%$ of individuals, i.e., the lethal concentration, was at waste-to-water ratio of 1:100 in all samples for all species, except for pure fresh slaked lime with the lethal concentration of 1:10. The calculated $50 \%$ lethal dose (LD 50\%) of spent carbide waste is presented in Tab. 5. It was calculated as $0.28-0.32 \mathrm{~g} / \mathrm{l}$ for fresh waste, which slowly decreased over time.

The seed germination tests on oats (Tab. 6) are indicative of a high toxicity of spent carbide in soils. In our 
control pots all 10 seedlings reached the height of $12 \mathrm{~cm}$ by the $7^{\text {th }}$ day and $21 \mathrm{~cm}$ by the $11^{\text {th }}$ day of experiment. In compost containing $10 \%$ of fresh waste (sample 1a) the number of germinated seed was twice as low, and the height of seedlings was $40 \%$ less than in control pots. The addition of fresh waste to compost at $50 \%$ totally suppressed oat seed germination over a period of two weeks. The waste exposed in the mine for a month (sample 1b) became less toxic at $10 \%$ and $25 \%$ concentrations, but remained lethal at $50 \%$ concentration. The waste became significantly less toxic after treatment in water (sample $1 c)$ : at $10 \%$ concentration its effect on seedlings was insignificant, and even at $50 \%$ concentration it caused only minor decrease in growth. The 13-year old waste (sample 5a) was still nearly as toxic as the fresh waste (1a).

The toxicity of spent carbide for heterotrophic microorganisms was tested in samples from the Nikitskaya Mine (Tab. 7). We revealed that the number of heterotrophic bacteria decreased under fresh waste deposit, but such effect was not very prominent and completely disappeared over time. These data generally agree with data by Lavoie (1980), apart from time estimations. According to our data, stabilization (recovery) of bacteria numbers in soil under waste deposit requires not just days, but weeks and, more probably, months.

\section{CONCLUSION}

The toxic effects of spent calcium carbide were detected in all our samples including those that were exposed under natural conditions for a long time. The wastes toxicity decreased over time due to the transformation of calcium hydroxide into calcium carbonate. However, such a natural neutralization process would take several years or decades in cases when a large deposit of the waste was present within a cave or mine.

The toxic compounds of the waste included: 1) calcium hydroxide (slaked lime), which accounts for highly-alkaline reaction upon contact of the waste with an aquatic medium, 2) strontium that was found at high concentrations in all samples of the waste and 3) polycyclic aromatic hydrocarbons derived from the organic matter used in high-temperature synthesis of calcium carbide. It should be mentioned that samples were free from toxic phosphorus compounds such as calcium phosphide, $\mathrm{Ca}_{3} \mathrm{P}_{2}$ (pre-cursor of phosphine, $\mathrm{PH}_{3}$, toxic gas) although it was expected to be there as an impurity (Marguard 1998). Such phosphorous compounds were probably completely burned together with acetylene.

Finding optimal solutions for the treatment of spent carbide presents a serious challenge. Clearly, banning the use of calcium carbide by cavers is the best way to bring an end to the waste disposal and ecological concerns connected with the emissions of toxic gases (primarily, phosphorus trihydride, carbon oxide, etc.) during carbide burning, significant changes in the temperature regime in certain caves, toxic effects of spent carbide on the caves biota and ground water quality deterioration. The use of electric lights instead of acetylene lamps is the current general advice for cavers (for example, according to the Cave conservation code of the New Zealand Speleological Society - caves.org.nz). However, waste treatment recommendations need to be developed for those cavers who are still reluctant to change from using acetylene lamps due to reasons of cost and effectiveness.

Another way of avoiding the negative impacts of the waste on cave ecosystems and the ground water quality is the removal of spent carbide from underground. However, the subsequent waste treatment either at the surface or underground still remains an important problem. Lavoie (1980) recommended that the waste should be placed into wet clays to speed up the neutralization of calcium hydroxides and disapproved of waste disposal in dry places, where it can retain its original properties for a long time. We have arrived at a different conclusion based on the evidence that wastes in the form of uncrushed lumps piled up together retain a high $\mathrm{pH}$ and toxic properties for many years. We believe that the waste treatment must ensure the complete isolation of spent carbide from aquatic media to prevent its dissemination with capillary moisture or any water flow. The most hazardous way to dispose of such waste is discard it directly into the flowing water. Indeed, such practice would result in a most drastic and significant release of pollutants, although the calcium hydroxide neutralization would occur rapidly within flowing water. Further potential hazards are connected with the carrying and deposition of relatively stable organic pollutants, such as benzopyrene, by water.

Spent carbide deactivation within concrete bowls filled with water (micro sediment bowls), which allows rapid emission of residual gas and temporarily isolates the waste the waste from the environment, is practiced in some countries. However, this method does not completely solve the problem as it cannot be used in flooded 
caves, and moreover, the sediment and toxic solution need further recycling.

We can recommend waste storing in water-proof containers with minimal risk of damage by running waters. Complete recycling could be achieved through the addition of deactivated waste to building materials such as cement that are meant to solidify and thus bound toxic compounds and exclude their dissolution. A technology developed in the former USSR (SN-290-74, 1974) involved the spent carbide deactivation by exposing the waste to the atmospheric conditions for two months.
A final conservation strategy should include not only the prohibition of use, but also a complete prevention of negative impacts on the environment and implementation of an alternative technology. The abovementioned industrial technology could probably be used for utilizing the existing waste storages in caves. The removal of old spent carbide from caves could decrease the potential hazard of water contamination, especially in flood risk areas.

\section{ACKNOWLEDGEMENTS}

The authors are grateful to Tatiana Shabarova and Oleg Morenkov for supplying us with samples from a cave in Switzerland, to Sergei Gusakov for providing us helpful information on the Nikitskaya Mine, to Yurii Evdokimov for fresh waste sample preparation, to Svetlana Mazina for supplying us with samples from the Snezhnaya Cave and to Inga Spiridonova for general advising.

\section{REFERENCES}

A dictionary of chemistry. 2004. Oxford University Press, pp. 602, Oxford, UK.

Agagabyan, M.M., 1955: On carbide residue’s bacterial capacity. ( $\mathrm{O}$ bacteritzidnych svoistvach ostatkov karbida).- Publications by the Zoological Institute of Erevan, 19, 5-12 (in Russian).

Conservation and protection of caves, 2010.- [Online] Available from: http://caves.org.nz/pmwiki/pmwiki.php/CCGExample/EthicalGuidelines [accessed $5^{\text {th }}$ April 2010].

Finney, D.J, 1971: Probit Analysis, $3^{\text {rd }}$ edition.- Cambridge University Press, pp. 305, Cambridge, UK.

Fitton, G., 1997: X-Ray fluorescence spectrometry.- In: Gill, R. (ed.) Modern Analytical Geochemistry: An Introduction to Quantitative Chemical Analysis for Earth, Environmental and Material Scientists. Addison Wesley Longman, pp. 87-115, Harlow, UK.

Lavoie, K.H., 1980: Toxicity of carbide waste to heterotrophic microorganisms in caves.- Microbial Ecology, 6, 2, 173-179.
Marguard, J., 1994: Carbide and phosphine data: Reprinted by permission from the caver's mailing list.- [Online] Available from: http://www.acave.us/ ccms/tc/1994maycc.htm [accessed $5^{\text {th }}$ April 2010].

Nelson, D.W. \& L.E. Sommers, 1996: Total carbon, organic carbon, and organic matter.- In: Page, A.L. et al. (ed.) Methods of Soil Analysis, Part 2,2 ed.,. Agronomy. Am. Soc. of Agron., Inc., pp. 961-1010, Madison, WI.

Peck, S.B., 1969: Spent carbide - a poison to cave fauna.Bulletin of the National Speleological Society, 31, 2, 53-54.

SN-290-74. Instruction on preparation and application of building mixtures. Approved by Order No.170 of GOSSTROY USSR, 19.08.1974 (in Russian). 